Sensationalism made Real: the role of realism in the production of sensational affect

Janice M. Allan

Associate Head of School (Academic)

School of Humanities, Languages and Social Sciences

Maxwell Building

University of Salford

Salford, Gr. Manchester

M5 4WT

j.m.allan@salford.ac.uk 


\section{Sensationalism made Real: the role of realism in the production of sensational affect}

"And yet I really don't know that a ghost might not be more awful in the broad sunshine." Mary Elizabeth Braddon, The Doctor's Wife (1864)

Like all complicated relationships, that between realism and sensationalism has been subject to a good deal of rumour and speculation. In what might be described as the pair's first critical encounter-an 1852 joint review of W.M. Thackeray's The History of Henry Esmond and Wilkie Collins's proto-sensation novel Basil-a critic for Bentley's Miscellany intimates that a partnership between two such different forms is anything but likely. "We have," he explains, "put these two books 'over against' each other, to use one of Mr. Thackeray's favourite Queen-Anne-isms, because they have no kind of family resemblance. They are, indeed, as unlike each other as any two books can be. They constitute a kind of literary antithesis" ("Esmond" 576). The inherently contradictory nature of this originary "'over against"' gesture-conflating proximity and distance, contiguity and difference — sets the keynote for subsequent discussions, contemporaneous and current, of a generic relationship that continues to attract and elude definition.

While it is now a critical commonplace to suggest that the sensation novel is a hybrid genre, what Lyn Pykett describes as "a catholic mixture of modes and forms" (4), there is also a long-standing tendency to construct the relationship between realism and sensationalism in oppositional terms. As Susan David Bernstein suggests, “sensation novels are measured and defined as realism's antithesis, in other words, as antirealism" (221). And while a number of critics, such as Winifred Hughes and, more recently, Deborah Wynne and Jennifer Phegley, have offered perceptive and nuanced readings of the relationship, claims that sensationalism "strongly diverged from 
mainstream realism" (Talairach-Vielmas 1) or, quite simply, is a "non-realist genre" that "eschews all loyalty to realism in order to achieve [its] ends," are still relatively common (Garrison 117, 3). It is, of course, undoubtedly true that realism was the critical yardstick against which sensationalism was routinely judged and found lacking by nineteenth-century critics; the reviews are littered with references to the texts" "unnatural," "improbable" and "artificial" characteristics. ${ }^{1}$ What is less well recognised is the extent to which these critics also acknowledged sensationalism's self-conscious appropriation of the representational strategies of realism.

Setting aside, for the moment, Margaret Oliphant's 1862 "Sensation Novels," in which she explicitly analyses the role of realism in creating sensational affect, we might note the assertion in Temple Bar that "Mr. Collins excites and fascinates our attention by an intense power of realism" ("Irish" 516), or the Spectator's suggestion that Jezebel's Daughter (1880) 'is told in the fantastically realistic way which Mr. Collins has uniformly affected" (“Jezebel's" 208). According to Henry James, the fame achieved by sensationalists such as Collins and Mary Braddon may be attributed to their "thoroughgoing realism" (593), while Dublin University Magazine praises Braddon's novels for the "intense realism which pervades" them ("Miss Braddon" 437). References, meanwhile, to "sensational realism" and "realistic sensationalism" appear across a variety of reviews from The British Quarterly Review, The Athenaeum and Saturday Review to The Academy, The Pall Mall Gazette, Dublin Review and even the Birmingham Daily Post. ${ }^{2}$ Returning to Bentley's review of Esmond and Basil, it is significant that when the critic turns from a discussion of the relationship between a realistic text and a sensational one, to the relationship between the realistic and the sensational within Collins's novel, he is forced to acknowledge that the situation becomes increasingly complex: 
There is a startling antagonism between the intensity of the passion, the violent spasmodic action of the piece, and its smooth, common-place environments. The scenery, the dramatis personae, the costumery, are all of the most familiar every-day type, belonging to an advanced stage of civilization; but there is something rude and barbarous, almost Titanic, about the incidents; they belong to a different state of society. But this very discrepancy enhances the terror of the drama; and there is something artistlike even in this apparent want of art. (586)

As this suggests, Basil's sensationalism (what the reviewer refers to, avant la lettre, as its "terror"), far from constituting an example of "antirealism," is produced when the two modes are brought into unexpected contact.

Given this early recognition of what I will go on to characterise as the supplemental relationship between realism and sensationalism, how might we account for an ongoing tendency to construct the pair in oppositional terms? In part, it stems from the fact that explorations of the relationship have tended to focus on how such generic classifications fed into contemporary constructions of literary value. As Phegley rightly asserts, "the controversy over [the sensation] genre was a subsetalbeit a dominant and domineering one — of the broader struggle to draw distinct lines of demarcation between high and low culture" (112). Given the nature of this "struggle," it is hardly surprising that explorations couched in such terms would prioritise distance and difference rather than proximity and contiguity. Richard Nemesvari's influential and often-cited article, “'Judged by a Purely Literary Standard': Sensation Fiction, Horizons of Expectation and the Generic Construction of Victorian Realism" provides a good example of both the strengths and drawbacks of this sort of reading. Arguing that "the formulation of 'the sensational' was an 
essential, constitutive strategy which reified 'the realistic' in ways which had been unachievable before" (17), he concludes that the "manifest purpose of the 1860s genre debate was to generate a canon of legitimate fiction. The point was not just to define realism and sensationalism in relationship to each other, but to generate a clear set of expectations that the first was superior to the second" (19). While Nemesvari's reading is convincing in terms of what it reveals about the generic codification of realism, as well as the sensation debate, it says relatively little about sensationalism itself. Relegated to the status of "an improper genre against which to define an acceptable realist standard" (18) — the canonisation of realism its only "use-value" (19) — sensationalism is no more or less than the literary handmaiden of realism. And thus, while Nemesvari undoubtedly sheds new light on the processes of genre formation, the role of the realistic within the sensational remains unexplored.

Taking as my exemplar Wilkie Collins's The Woman in White (1859-60), this essay will reverse the terms of the dichotomy identified by Nemesvari in order to explore the "essential, constitutive" role of realism in "the formulation of "the sensational.",3 Concentrating on the novel's two moments of "pure sensation" (Oliphant 572) - Walter Hartright's encounter with Anne Catherick on the road to London and his subsequent recognition of the resemblance between this woman and Laura Fairlie-I hope to illuminate the extent to which the sensational and the realistic are inextricably entwined in the production of sensational affect, even as former interrogates the epistemological and ideological foundations of the realistic impulse on which it depends. ${ }^{4}$

\section{On the "well-known, uneventful road" to London}

The scene in which Anne lays her hand upon Walter's shoulder is, perhaps, the iconic moment of sensationalism. Identifying it as "the novel's 'primal scene," 
D.A. Miller sets the tone for many modern readings by anchoring his analysis to the moment when Anne's hand makes contact with Walter's body (152). ${ }^{5}$ And yet, this too exclusive focus on the scene's climax fails to recognise the extent to which the affective potential of Anne's touch depends upon its context: both the familiarity of the setting and Walter's own psychological state. When Walter leaves his mother's house, his spirits are "not to be commanded" while his surroundings, "the broken ground of the heath," appear "wild enough in the mysterious light to be hundreds of miles away from the great city that lay beneath" them (62). In such a state of mind and environment, an "extraordinary apparition" (63) would not be out of place, but this is precisely why it could not, thus situated, produce sensational affect. It is, however, significant that a slow walk through the heath, enjoying the "divine stillness of the scene," has, by the time Walter reaches the "well-known, uneventful road" to London (63), produced a more heimlich (open, comfortable, unguarded) state of mind:

I had mechanically turned in this latter direction, and was strolling along the lonely high-road - idly wondering, I remember, what the Cumberland young ladies would look like — when in one moment, every drop of blood in my body was brought to a stop by the touch of a hand laid lightly and suddenly on my shoulder from behind me. I turned on the instant, with my fingers tightening round the handle of my stick.

There, in the middle of the broad, bright high-road - there, as if it had that moment sprung out of the earth or dropped from the heaven-stood the figure of a solitary Woman, dressed from head to foot in white garments.

Although this figure in white has come to be read as a metonymic totem for the sensation genre as a whole, there is nothing to suggest that the affective potential of 
her touch arises, in and of itself, from any inherent quality within her person. Instead, Anne potential to affect both Walter and, through him, the reader, depends upon the sensational body being brought into a homely environment (perhaps the home itself) in which it has no place. And thus, while a number of critics have commented on the intensity of the sensation produced within Walter in this scene,${ }^{6} \mathrm{I}$ am more interested in the purported speed with which the two bodies and two worlds are brought together: as described, both Anne's appearance and the sensational affect produced by her touch are instantaneous. Analysing the role of sensation fiction in modernising the senses of its readers, Nicholas Daly, adopting the metaphor of the railway, describes the encounter between Walter and Anne as a "collision" (36). But even while serving as the "agent and icon of the acceleration of the pace of everyday life" (37), the railway seems too slow, not to mention too heavy and cumbersome, to capture the speed of sensational affect in this scene. In contrast, I would argue that it is the electric telegraph — an even more effective means of "annihilating an older experience of time and space" (Daly 37) - that provides the most apt metaphor for the instantaneous transmission of affect represented in this scene.

In a discussion of the links between advanced technologies, mass culture and sensation fiction, Phegley suggests, with reference to an 1869 Belgravia article, "A Day in a Telegraph Office," that, "like the genre of sensation fiction, telegraph messages ... described extreme events that were nonetheless true" (149). While this is undoubtedly correct, it is not the only or perhaps even the most telling of the similarities between them. Indeed, the message that makes the most vivid impression upon the author of the Belgravia article is one in which sensational content is heightened by the immediacy of the medium. 
"Here, Ned! send your brother here," said a clerk: "rather a bad murder this."

"Found dead, with his throat cut from ear to ear, and a lock of dark hair, that of a woman, in his hand; clothes, jewlry [sic], \&c. answer to your description. Send at once. No doubt about it being a murder."

Here was an atrocious murder committed, as I saw by the address, only fifty miles away; and as the message added, "Body still warm," there was a reality about it that influenced me as much as if I had seen the gory corpse. (C.W. 316)

As this passage suggests, the "reality" of the situation-a reality that transports the author to the crime scene in bringing the crime scene to him-depends upon an evocation of proximity. ${ }^{7}$ This proximity, however, arises not simply from the details of the telegraph - a body still warm, less than fifty miles away—but, crucially, from the speed with which this news breaks in upon and disturbs the familiar environment and mindset of the receiver. Writing of the role of the electric telegraph in apprehending the murderers John Tawell (1845) and Harvey Crippin (1910), Richard Menke suggests that, "with its weightless, instant travel on the wire or in the ether, an electric message can outrun any murderer" (73). But, by the same token, it can transport crime and murder into the familiar and homely environment of the receiver just as quickly, collapsing the geographical and psychological buffer zone between the safe and the sensational. Mimicking the same "over against" gesture that we encountered in the Bentley review, this "strange machine"-conflating proximity and distance - "enables one side of a country to speak with another, regardless of the intervening hundreds of miles of hills, streams, and plains: solitudes and cities" (Hunt 241). Thus, when watching a demonstration of telegraphy in action, Frederick Knight 
Hunt, writing for Household Words, marvels that it was "as though Dover was bodily in the room at Tonbridge, and was giving his explanation by word of mouth" (242). Through such "curiously instantaneous results" (243), the electric telegraph brought worlds — and bodies — together.

Turning back to Walter's encounter with Anne Catherick, I would suggest that her touch, much like an electric telegraph, marks the moment when the familiar realm of "the broad, bright high-road" (63), the familiar realm, one might add, of domestic realism, is touched by the strange and sensational. Here, as in Basil, it is the "startling antagonism" between different representational and psychic modes that produces sensational affect. And thus, if the sensational "reified 'the realistic' in ways which had been unachievable before," as Nemesvari suggests, so too did the realistic reify, make real or concrete, the sensational.

In this sense, the production of sensational affect functions much like the production of the uncanny. "The whole thing is," to borrow Freud's words, "purely an affair of 'reality-testing,' a question of the material reality of the phenomena" (371). Like the uncanny, the sensational "retains its character ... so long as the setting is one of material reality; but where it is given an arbitrary and artificial setting in fiction, it is apt to lose that character" (Freud 375). It is on these exact grounds that Great Expectations (1861), according to Oliphant, fails as a sensation novel: "with the most fantastic exaggeration of means, here is no result at all achieved, and no sensation produced upon the composed intelligence of the reader" (577). Collins, in contrast, "ignores all these arbitrary sensations, and has boldly undertaken to produce effects as startling by the simplest expedients of life.... everything is legitimate, natural and possible" (566). Indeed, for Oliphant, an author's ability to produce sensation is directly linked to his or her ability to manipulate the signs and strategies of realism. 
The "more we perceive the perfectly legitimate nature of the means used to produce the sensation," she argues, "the more striking does that sensation become" (566). This assumption is re-iterated in the Saturday Review's assessment of Ellen Wood's 1864 sensation novel Lord Oakburn's Daughters: the "interest in such cases being naturally in proportion to the apparent reality of the incidents, it is of course a test of the writer's art how far that air of reality has been imparted to the fictitious narrative" (Lord 488). Yet it is, perhaps, Alexander Innes Shand who best captures the role of realism in the reification of the sensational and hence the production of sensational affect. In the "modern sensational school," he reminds his readers:

Murder stalked with stealthy tread up the back staircases of the most highlyrented houses; bravoes, disguised in powdered hair and gorgeous liveries, draw their chairs sociably to the tables in servants' halls; mothers made away with their children as if they were ordering the execution of a litter of puppies. Had all that been bluntly told, it would have sounded unnatural and extravagant in a police report. But writers like Miss Braddon had undoubtedly the talent of mixing it up with the realistic, so as to throw an air of possibility over the whole. You might have been slow to give Lady Audley credit for the vice which belied her beautiful face; but any scene appeared dramatically conceivable, when you had been made so thoroughly at home in the surroundings. (332, 333; emphasis added)

Thus, as is only appropriate for a genre that uncovers the secret and hidden within the homely and familiar, the forces of realism and sensationalism — like Freud's pairing of heimlich and unheimlich-grow ever closer, inextricable.

\section{A Supplemental Relationship}


To explore this relationship further I would like to turn to the novel's second sensation incident: Walter's recognition of the uncanny resemblance between Anne and Laura Fairlie. If Anne is the quintessential figure of sensation, Laura may be said to represent the typical heroine of domestic realism. At the very least, she possesses a number of the "womanly" qualities - most obviously, loyal domesticity and patient endurance - valued by a mode of representation that aims to promulgate appropriate moral values and support the socialisation of young women into properly feminised subjects. Equally important, she embodies the social elevation that rewards the honest efforts of the middle-class hero within realism's typical narrative of bourgeois ascendancy. Yet if this is, indeed, the case, then Walter's recognition of the resemblance between Laura and Anne has important implications for the relationship between realism and sensationalism more generally.

Walter's perception of Laura is, prior to this moment of recognition, characterised by an undefined lack: "mingling with the vivid impression produced by the charm of her fair face and head, her sweet expression, and her winning simplicity of manner, was another impression, which, in a shadowy way, suggested to me the idea of something wanting.... and where it was, and what it was, I could not say" (91). Given what I have argued above, it is not irrelevant that the answer to this riddle flashes upon Walter while he is ensconced in the homely realm of quiet domesticity: "that peaceful home-picture of the drawing-room" where the "sense of peace and seclusion soothed all thought and feeling" (95). Listening to Marian recount Mrs. Fairlie's history of Anne Catherick, while Laura passes and re-passes through his frame of vision:

A thrill of the same feeling which ran through [him] when the touch was laid upon [his] shoulder on the lonely high road, chilled [him] again. 
There stood Miss Fairlie, a white figure, alone in the moonlight; in her attitude, in the turn of her head, in her complexion, in the shape of her face, the living image, at that distance and under those circumstances, of the woman in white! The doubt which had troubled [his] mind for hours and hours past flashed into conviction in an instant. That "something wanting" was [his] own recognition of the ominous likeness between the fugitive from the asylum and the heiress of Limmeridge House. (99)

Once again mimicking the "curiously instantaneous results" of the electric telegraph, Walter is, "in an instant," transported across time and space, from the homely domestic atmosphere of the drawing room, back to the moonlit road where he first experienced Anne's touch. Here, again, the production of affect depends, in large part, on a sudden connection between two worlds and two bodies that should remain discrete and separate. And crucially, the sensational resides, like the answer to Walter's query, not in one or the other but in the relationship between them. ${ }^{8}$ It arises, like the uncanny, only from "a peculiar commingling of the familiar and unfamiliar" (Royle, Uncanny 1).

It thus appears that the relationship between Laura and Anne-and, by extension, realism and sensationalism — follows the "logic" of what Jacques Derrida, citing Rousseau, calls "ce dangereux supplément." Evoking ideas of both supplementation and (crucially, given the novel's plot) substitution, the Derridean supplement offers itself as a particularly apposite trope to describe the relationship between these two characters. Most appropriately, it "harbors within itself two significations whose cohabitation is as strange as it is necessary." According to the first signification, the supplement "adds itself, it is a surplus, a plenitude enriching another plenitude" but, at the same time, "the supplement supplements. It adds only to 
replace. It intervenes or insinuates itself in-the-place-of; if it fills, it is as if one fills a void" (Derrida 144-5). And thus, "the supplement entails a kind of crazy logic: it is neither inside nor outside, and/or both inside and outside at the same time. It forms part without being part, it belongs without belonging" (Royle, Jacques 49). The "crazy logic" that characterises Anne and Laura's supplemental relationship is captured most forcibly in her ambiguous position vis-à-vis the family. As Laura's illegitimate half-sister, Anne both belongs and does not belong: "neither inside nor outside, and/or both inside and outside at the same time." Moreover, despite being figured, as the titular woman in white, as a blank or absence, Anne nevertheless possesses the something "extra" that allows her to "complete" Laura's identity. Yet in supplying what is "wanting" within Laura, Anne simultaneously endangers her, revealing the void that characterises her psychic and social identities.

Following an equally "crazy logic," the realistic, I would argue, is what is added to the sensational as its necessary pre-requisite. For as Nicholas Royle reminds us, "there has to be a sense of home and homeliness within and beyond which to think the unhomely" (Uncanny 25). It is not, perhaps, insignificant that The Doctor's Wife (1864)—Braddon's self-conscious experiment in realistic writing-makes precisely this point. When Roland Lansdell, the focus of the Isabel Gilbert's romantic fantasies, happens to mention that his premature death has been foretold, his cousin, Lady Gwendoline, begs that he tell the story, while acknowledging that she cannot "promise to be very much frightened because the accessories are not quite the thing for a ghost-story."

If it were midnight now, and we were sitting in the oak room, with the lights burning low, and the shadows trembling on the wall, you might do what you liked with our nerves. And yet I really don't know that a ghost might not be 
more awful in the broad sunshine - a ghost that would stalk across the grass, and then fade slowly, till it melted into the water-drops of the fountain. (Braddon, Doctor's 177; emphasis added)

Here, as in The Woman in White, the realistic is an indispensable "extra," a necessary surplus, in the production of the sensational; it is that which "forms part without being part" and "belongs without belonging." Collapsing the boundaries between inside and outside, the familiar and the strange, the realistic and the sensational hold their trysts in the ambiguous space where the heimlich shades into the unheimlich.

And yet, if the sensational and realistic exist in a relationship of supplemental intimacy, realism does not emerge from this encounter unscathed. Derrida's supplement is, after all, dangerous. According to Miller's somatic reading of Anne and Walter's first encounter, her touch marks the moment when "released from-and with - the Woman, nervousness touches and enters the Man" (152). "Nervousness," however, does not adequately capture the ontological crisis unleashed within Walter by Anne's touch. Indeed, the affective potential of this touch suggests that it is better read as what Carolyn Dinshaw designates as "the touch of the queer": a touch that "releases" the uncanny strangeness at the heart of the familiar.

There can be no doubt that sensation fiction lends itself well to such queer readings. ${ }^{9}$ As defined by David Halperin, queer designates "whatever is at odds with the normal, the legitimate, the dominant. There is nothing in particular to which it necessarily refers. It is an identity without an essence. 'Queer' then, demarcates not a positivity but a positionality vis-à-vis the normative" (62). As such, it represents a particularly apposite methodology through which to read a genre that is, more often than not, "constructed not as a unified form, but as an alterity against which opposed literary/cultural expectations may be recognized" (Nemesvari 18). The queer, no less 
than the sensational and the uncanny, is "a relational signifier" (Cixous 537). Furthermore, as an effect produced by a text, rather than a quality inhering within it (like the uncanny and the sensational, it is an effect of reading), the queer imposes no artificial unity upon the formally and thematically diverse body of writings deemed sensational. Thus Dinshaw's "touch of the queer" holds great promise for an exploration of the sensational, especially in its relationship to realism. As she suggests, this "dissonant hand" "renders what it touches unnatural, makes it strange,,.. it is arresting: it makes people stop and look at what they have been taking as natural and it provokes an inquiry into the ways that 'natural' has been produced by particular discursive matrices" (77).

Following the logic of Dinshaw's argument, the touch of Anne's “dissonant hand"- the quintessential touch of sensation itself - effectively queers the world of realism upon which it intrudes. It is the force that renders Walter's homely environment and heimlich mindset strange by provoking an inquiry into what appears "natural" and familiar. For another salient example of this process at work, we can turn, once again, to The Doctor's Wife and the return of Mr Sleaford, Isabel's criminal father:

There was nothing uncommon in a late knocking at the doctor's door,- - some one from the lanes wanted medicine, no doubt; the people in the lanes were always wanting medicine. Mrs Gilbert opened the door, and looked out into the darkness. A man was standing there, a well-clad rather handsome-looking man, with broad shoulders, bold black eyes, and a black beard that covered all the lower part of his face. He did not wait to be invited to enter, but walked across the threshold like a man who had a right to come into that 
house. At first she only stared at him with a blank look of wonder, but all at once her face grew as white as the plaster on the wall behind her.

"You!" she gasped, in a whisper; "you here!"

"Yes, me! You needn't stare as if you saw a ghost. There's nothing so very queer about me, is there?" (309-10)

Sleaford's final assertion is correct in so far that his queerness arises only from the “positionality” captured in Isabel's exclamation, “'you here!” Having “dropped as it were from the clouds into Midlandshire," the "single cautious knock" of his hand $(314,309)$ collapses the boundaries-temporal, geographical and psychologicalbetween Roland's sensational narrative of pre-destined death (in which Sleaford plays the role of murderer) and the prosaic realism of Isabel's life. It is, therefore, hardly surprising that "no language can describe the horror that she felt on her father's sudden appearance" (360). His is the "denaturalizing" touch that renders queer Isabel's all too heimlich home.

Etymologically related to the German quer, meaning transverse, oblique, crosswise, at right angles, a sidewise glance ("queer, adj.1"), the queer thus appears to allow for a new perspective on the realistic, one that reveals the uncanny strangeness at its heart. Like the titular Lady Audley's pre-Raphaelite portrait, the sensational, through its queer touch, is able to reveal "through the normal expression of the face, another expression that is equally a part of it, though not to be perceived by common eyes" (Braddon, Lady 108). It is, therefore, only appropriate that Robert Audley feels decidedly unsettled by this process of denaturalisation as the verb "to queer" means not only to inquire or question but, in addition, to confound, baffle, to put out of order, to spoil and, finally, to disconcert or perturb ("queer, v.2"). Consider, as a case in point, Walter's reaction to the disturbance created by Anne's touch: "It was like a 
dream. Was I Walter Hartright? Was this the well-known, uneventful road, where holiday people strolled on Sundays? Had I really left, little more than an hour since, the quiet, decent, conventionally-domestic atmosphere of my mother's cottage" (67)? This "well-known, uneventful road" and "decent, conventionally-domestic atmosphere" is the recognisable world of domestic realism, the ground upon which the familiar trials and tribulations of middle-class subjectivity are played out. Yet, infected by the touch of the queer, it is suddenly denaturalised; no longer taken for granted, it is open to suspicion. Through this touch, the "material surface of things, even in that most familiar of settings, the bourgeois home, themselves become double, treacherously unstable, disguises for the most buried, traumatic secret" (Brantlinger 161). Reaching out from the page, the touch of the queer "disturbs ... the reader's sense of the stability of things, and opens a new, untried vista of what may be" ("Our Female" 211); it makes the "audience uncomfortable without letting them know why" (“Armadale" 726). ${ }^{10}$

\section{De-naturalising Realism}

It is important to recognise, however, that the touch of the queer proffered by sensation fiction does not simply denaturalise the domestic setting and material environment of domestic realism. More profoundly, this touch extends to the epistemological foundations of the genre itself. As Beth Palmer has recently argued, sensation fiction is a "self-conscious and performative" genre; one that "flags up its own instability through exaggeration or self-conscious emphases on tropes and conventions" $(11,13)$. I would like to suggest that the performative element of sensation fiction is, perhaps, most obvious in its deployment of the generic conventions of realism. Consider, as a single example, the sensationalists' incorporation of the "factual" or "true" within their narratives. As Charles Reade, for 
instance, famously wrote to the editor of The Times: "for 18 years, at least, the journal you conduct so ably has been my preceptor, and the main source of my works" (323). And yet, according to the tenets of realism, such facts, while true, remain "unreal." For as Herbert Stack, writing in the Fortnightly Review, suggests:

A skilful story-teller makes the pain and trouble flow naturally from natural and commonplace and inevitable events... That in real life great effects from little causes spring, is no sufficient justification. In real life we accept such facts because they are facts; but in reading a novel, the whole groundwork is so necessarily make-believe, that the facts must seem very natural to make us forget their unreality. (743)

In privileging the factual in all its "unreality," the sensation genre, as Phegley asserts, "served as an implicit challenge to the core values of realism" (113). And yet, what has not yet been adequately recognised is that this "challenge" is distinctly performative in nature. Judith Butler has argued that "when the unreal lays claim to reality, or enters its domain, something other than a simple assimilation into prevailing norms takes place" (27). Following this logic, I would suggest that, while the realistic and the sensational are inextricably bound up in the production of sensational affect, at no point are they simply assimilated. Indeed, sensationalism's exaggerated and self-conscious incorporation of the factual and the true effectively turns realism into a spectacle. By re-locating the signs and tokens of realism to the realm of the sensational, they are effectively framed; a gesture that invites the reader to pause and take note of the normally "invisible" disjunction between the "true" and the "real."

Readers had, arguably, been trained to recognise the defamiliarising effects of such framing through the Great Exhibition of 1851. As Thomas Richards suggests, the 
Exhibition's system of spectacular representation introduced "a new way of seeing things," one which "exalted the ordinary by means of the extraordinary, the small by means of the large, the real by means of the unreal" (18; 4). Building on Richards' argument, Lynn Voskuil explains that the objects on display "existed solidly as things with a manufactured, material presence; yet they were also encased in glass, isolated from both their makers and the viewers who were being trained (by the very arrangement of the Exhibition itself) to consume them merely by looking, not by touching or actually using them. They thus acquired a certain aura of the fantastic at the same time that they were also recognized as common, useable items" (76; emphasis added). Turning back to the realm of fiction, Ellen Wood's St. Martin's Eve (1866) offers a particularly apposite example of such denaturalisation at work. For those not familiar with the novel, it is worth explaining that it has two distinct sensational climaxes: the revelation of Charlotte St. John's involvement in the death of her young stepson and the reception of the dead in which the body of Adeline de Castella, in all her wedding finery, is, quite literally, "exhibited" (348) and put on "show" (361): "'You-you will pass and look at her: as we look at a picture"” (363).

It is significant that the author insists that this French custom, however inconceivable to her English readers, is firmly based in "fact" (351): "You may look upon its chief incident as a disagreeable fiction; but it was sober fact, truthful reality" (356). Wood, moreover, echoes George Eliot in her promise to "transcribe it for you as exactly and faithfully as I can" (356). ${ }^{11}$ The impact of the scene that follows arises from the "startling antagonism" between different representational and psychic modes which, while inextricably bound together, cannot be reconciled.

Mr. St. John continued his way, ever and anon catching a glimpse of the rigid form opposite, before which we were all filing. 
"It cannot be Adeline!" he exclaimed involuntarily. "And yet it is like her! Who is it? What is it? How strange she looks!" ....

Oh, the rich and flowing robes in which they had decked her! white satin, covered with costly lace; white ribbons, white flowers, everything about her white; the festive attire of a bride adorning the upright dead, and that dead worn and wasted! A narrow band of white satin was passed tightly under the chin, to keep the jaw from falling, but it was partly hidden by the hair and the wreath of flowers, and the veil that floated behind her.... To a stranger entering the room, unsuspecting the truth, as Mr. St. John, she looked like one fearfully ill, fearfully strange: and how was Mr. St. John, who had never heard of the custom, to divine the truth? Did the idea occur to him that Adeline was standing in the very spot where he had first met her, a year before, when the French marigold in his button-hole was accidentally caught by her?...

He went close up, and halted in front of her: Rose by him, shaking from head to foot. Forgetting, probably, what Rose had said, that she would not speak to him, or else obeying the impulse of the moment, he mechanically held out his hand to Adeline: but there was no answering impulse on her part.

He stood rooted to the spot, his eyes running rapidly over her. They glanced down on the flounces of the rich lace dress, they wandered up to her face - it was the first close, full view he had obtained of it. He saw the set, rigid features, the unmistakable stare of the glassy eye; and, with a rushing sensation of sickening awe and terror, the terrible truth burst upon his brain. 
That it was not Adeline de Castella, but her CORPSE which stood there. $(363-4)$

In this scene the reader's attention is divided between the spectacle of the girl's body - a performance that parodies the passivity of proper femininity and the death of autonomous female identity in marriage — and St. John's reaction to this spectacle: both a spectacle in and of itself and a framing device through which the primary performance is viewed. For St. John, as for Walter Hartright, the sensational arises out of the sudden and unexpected contact between two worlds and two bodies-one living and one dead - that should have remained discrete and separate. Its affects, moreover, are similarly instantaneous: "with a rushing sensation of sickening awe and terror, the terrible truth burst upon his brain.” Regardless of whether St. John's hand, held out to Adeline, makes contact with her body, this is the moment when the touch of the queer is unleashed, provoking an ontological crisis that throws the known and familiar world into disarray. It is significant, however, that the experience of the reader is somewhat different. Although the scene is focalised through St. John's unsuspecting eyes, the reader's prior knowledge of what is about to occur-together with the overt and exaggerated theatricality of the situation-provides sufficient distance to render the process of denaturalisation visible; to put it, as it were, on display. As St. John maneuvers through the crowd, "ever and anon catching a glimpse of the rigid form opposite," he is both spectator and spectacle. Through this "self-conscious and performative" doubling, the reader is able to anticipate and take note of the precise moment when, "the unreal lay[ing] claim to the real," the rules of realism are thrown into question.

St. Martin's Eve thus provides a salient, if extreme, reminder of how sensation fiction, like the touch of Dinshaw's "dissonant hand," has the power to make "people 
stop and look at what they have been taking as natural and [to] provokes an inquiry into the ways that "natural' has been produced." A form of repetition with a difference, sensationalism's exaggerated realism, what Phegley terms its hyperrealism (26), is effectively a performance in drag: a "copy of a copy [that] puts the category of the original into crisis" (Jenzen 7). Like the bigamous marriages that dominate so many sensational plots, it is - as is Adeline's staged femininity at the reception - a type of repetition as/and difference that reveals the artificiality and constructedness, not simply of the form being imitated but also its values and ideological assumptions.

Consider, as a case in point, the Saturday Review's assessment of Antony Trollope's The Claverings (1867). According to the critic, Trollope's popularity stems from his "exceedingly truthful" realism: he "reproduces the world very much in those aspects which it wears in the eyes of most of us." And yet it is almost immediately acknowledged that:

One of the most conspicuous of [Trollope's] characteristics is his strong belief in the general justice of things. He has a wonderful faith in respectability, and he would think ill of himself if he should write anything to make one suppose that iniquity is ever triumphant. This may be another reason why his stories are so pleasant. It is a comfort to believe that our suspicions as to the cruelty and injustice stalking around us are, after all, without foundation. In the Claverings this presence of the respectable god of social justice is perhaps more remarkable than in any previous book from the same hand. Everything turns out just as our belief in the general comfort of the universe requires that it should do. (638)

As this passage suggests, the realistic genre was defined as much by its adherence to middle-class ideologies and myths of bourgeois triumph—where "anybody who plays 
his cards as he ought to do can make sure of a competence of cash and a comfortable wife and a thoroughly respectability position before his fellows" (638) - as its verisimilitude. And despite the obvious incompatibility between these two representational principles, the genre's popularity and power stemmed largely from its ability to assimilate the former into the latter and, in so doing, naturalise it. For as Butler suggests, "Having or bearing 'truth' and 'reality' is an enormously powerful prerogative within the social world, one way that power dissimulates as ontology" (27). It is, in this respect, interesting to note the frequency with which realistic novels were described, by their critics, as "homely."12 This designation arguably refers as much to the feelings of heimlich familiarity they evoke as their material environment and subject matter; a familiarity that played a crucial role in establishing middle-class ideologies as hegemonic. Possessing the same destabilising effects of the uncanny, sensation fiction, in contrast, was able to provoke "a crisis of the natural, touching upon everything that one might have thought was 'part of nature': one's own nature, human nature, the nature of reality and the world" (Royle, Uncanny 1). Indeed, it is possible that the genre was labelled "unnatural" precisely because it made "the natural" problematic. It uncovered not only the unpalatable secrets hidden within the middle-class home but those lurking within realism itself.

It is, then, little wonder that sensationalism's contemporary critics reacted to its powers of denaturalisation with overt hostility. Constructing the genre as "a pestilence so foul as to poison the very life-blood of our nation" (Murray 935) and a vehicle "calculated to shake that mutual confidence by which societies and, above all, families are held together" ("Recent" 108), a significant number of the reviews betray an otherwise inexplicably exaggerated fear of the dangers, both moral and social, posed by the nation's light reading. Littered with allusions to disease, contamination 
and degeneration - the discursive fields that came to dominant the debate - the contemporary reviews appear to recognise that the sensation novel posed a threat not simply to literary standards, but to the bedrock of values that ground the English middle-class subject.

While it would be an exaggeration to claim that sensationalism, in its relationship to realism, has played the role of the misunderstood or neglected partner, it is fair to say that the role of the realistic within the sensational has not yet been fully recognised and demands further attention. If genre acts as "a set of reading instructions anterior to the text itself" (Gilbert 59), then sensational affect is produced when two seemingly antithetical sets of instruction —one associated with the realistic and one with the sensational-intersect at particular moments in a text, causing the sensational to be read and experienced, however fleetingly, as real and the real to be experienced, uncannily, as sensational. And yet, while engaged in an inextricable, intimate embrace in the production of this affect, sensationalism's queer touch cannot help but raise questions about the efficacy and trustworthiness of the realist perception upon which it depends. Complex, contradictory and supplemental, the "crazy logic" governing the relationship between the realistic and the sensational suggests that it will continue to demand our attention, while eluding our definitions, for some time to come. 


\section{Works Cited}

“Armadale.” Rev. The Saturday Review 21 (16 June 1866): 726-7. Print.

"Atherstone Priory." Rev. Saturday Review 18 (1 October 1864): 430-1. British Periodicals. Web. 11 Jan. 2011.

Austin, Alfred. "Our Novels: the Sensational School.” Temple Bar 29 (1870): 410-24. Print.

Bernstein, Susan David. "Dirty Reading: Sensation Fiction, Women and Primitivism." Criticism 36.2 (1994): 213-41. Print.

Braddon, Mary Elizabeth. The Doctor's Wife. 1864. Ed. Lyn Pykett. Oxford: Oxford UP, 1998. Print.

---. Lady Audley's Secret. 1862. Ed. Natalie Houston. Peterborough, Ont.: Broadview $\mathrm{P}, 2003$. Print.

Brantlinger, Patrick. The Reading Lesson: The Threat of Mass Literacy in NineteenthCentury British Fiction. Bloomington and Indianapolis: Indiana UP, 1998. Print.

Butler, Judith. Undoing Gender. London: Routledge 2004. Print.

C.W. "A Day in a Telegraph Office." Belgravia: a London Magazine (September 1869): 314-18. British Periodicals. Web. 13 June 2011.

Cixous, Hélène. "Fiction and Its Phantoms: A Reading of Freud's Das Unheimlich (The 'Uncanny')." Trans. Robert Dennomé. New Literary History 7.3 (1976): 525-48. Print.

“The Claverings." Rev. The Saturday Review 23 (18 May 1867): 638-9. British Periodicals. Web. 11 Jan. 2011.

Collins, Wilkie. The Woman in White. 1860. Ed. Maria Bachman and Donald Cox. Peterborough, Ont: Broadview P, 2006. Print.

"The Cotton Lord." Rev. London Review (17 May 1862): 464-5. British Periodicals. Web. 11 Jan. 2011.

Cvetkovich, Ann. Mixed Feelings: Feminism, Mass Culture and Victorian Sensationalism. New Brunswick, NJ: Rutgers UP, 1992. Print.

Daly, Nicholas. Literature, Technology, and Modernity, 1860-2000. Cambridge: Cambridge UP, 2004. Print.

Derrida, Jacques. Of Grammatology. 1967. Trans. Gayatri Chakravorty Spivak. Baltimore and London: John Hopkins UP, 1976. Print. 
Dinshaw, Carolyn. "Chaucer's Queer Touches/A Queer Touches Chaucer." Exemplaria 7.1 (1995): 75-92. Print.

Eliot George. 1859. Adam Bede. Ed Stephen Gill. London: Penguin, 1985. Print.

“"Esmond' and 'Basil."” Rev. Bentley's Miscellany 32 (July 1852): 576-86. British Periodicals. Web. 08 Oct. 2010.

"For the King." Rev. The British Quarterly Review 56 (July 1872): 255. British Periodicals. Web. 11 Jan. 2011.

Forman, Ross G. "Queer Sensation.” A Companion to Sensation Fiction. Ed. Pamela K. Gilbert. Chichester: Wiley-Blackwell, 2011. 414-29. Print.

Freud, Sigmund. "The "Uncanny." Trans. James Strachey. The Penguin Freud Library. Ed. Albert Dickson. Vol 1. Art and Literature. London: Penguin, 1990. 335-76. Print.

Garrison, Laurie. Science, Sexuality and Sensation Novels. Basingstoke: Palgrave Macmillan, 2011. Print.

Gilbert, Pamela. Disease, Desire and the Body in Victorian Women's Popular Novels. Cambridge: Cambridge UP, 1997. Print.

Halperin, David. Saint Foucault: Towards a Gay Hagiography. New York: Oxford UP, 1995. Print.

Hughes, Winifred. The Maniac in the Cellar: Sensation Novels of the 1860s. 1980. Ann Arbor, MI: UMI Books on Demand, 2006. Print.

Hunt, Frederick Hunt. "Wings of Wire.” Household Words 7 December 1850: 241-5. Print.

“An Irish Poet and Novelist.” Temple Bar 50 (August 1877): 504-17. 11 Jan. 2011. Print.

James, Henry. "Miss Braddon.” Rev. of Aurora Floyd. The Nation 1.19 (November 1865): 593-4. Print.

Jenzen, Olu. 'The Queer Uncanny', eSharp 9 (Spring 2007): 1-16. Web. 07 June 2011.

“Jezebel's Daughter.” Rev. Spectator 53 (15 May 1880): 627-8. Print.

“Loyal and Lawless.” Rev. The Saturday Review 49 (13 March 1880): 355-6. British Periodicals. Web. 11 Jan. 2011.

“Lord Oakburn's Daughters." Rev. Saturday Review (15 October 1864): 488-9. British Periodicals. Web. 07 July 2011. 
Mangham, Andrew. “'What Could I Do?': Nineteenth-Century Psychology and the Horrors of Masculinity in The Woman in White." Victorian Sensations: Essays on a Scandalous Genre. Ed. Kimberly Harrison and Richard Fantana. Columbus, OH: Ohio State UP, 2006. 115-25. Print.

Mansel, Henry L. "Sensation Novels." Quarterly Review 113 (April 1863): 481-514. Print.

Menke, Richard. Telegraphic Realism: Victorian Fiction and Other Information Systems. Stanford CA: Stanford UP, 2008. Print.

Miller, D.A. The Novel and the Police. Berkeley and Los Angeles, CA: U of California P, 1988. Print.

“Miss Braddon's Novels.” Dublin University Magazine 75 (April 1870): 436-45 (437). Web. 12 Jan. 2011.

Murray, Vincent E.H. “Ouida's Novels.” The Contemporary Review 22 (1878): 92135. Print.

Nemesvari, Richard “'Judged by a Purely Literary Standard”: Sensation Fiction, Horizons of Expectation and the Generic Construction of Victorian Realism." Victorian Sensations: Essays on a Scandalous Genre. Ed. Kimberly Harrison and Richard Fantina. Columbus, OH: Ohio State UP, 2006. 15-28. Print.

"New Books." Rev. of The Crime of Maunsell Grange. Birmingham Daily Post 7 July 1893: 3. $19^{\text {th }}$ Century British Library Newspapers. Web. 11 Jan. 2011.

"New Novels." Rev. of The Master of St. Benedict's. Academy (1 April 1893): 281-2. British Periodicals. Web. 11 Jan. 2011.

"Notices of Books." Rev. of Linked Lives. Dublin Review (July 1876): 273-5. British Periodicals. Web. 11 Jan. 2011.

Oliphant, Margaret. “Sensation Novels.” Blackwood's Edinburgh Magazine 91 (May 1862): 564-84. Print.

"Our Female Sensation Novelists." The Christian Remembrancer 46 (July 1864): 209-36. Print.

Palmer, Beth. Women's Authorship and Editorship in Victorian Culture: Sensational Strategies. Oxford: Oxford UP, 2011. Print.

Phegley, Jennifer. Educating the Proper Woman Reader: Victorian Family Literary Magazines and the Cultural Health of the Nation. Columbus $\mathrm{OH}$ : Ohio State University Press, 2004. Print.

Pykett, Lyn. The Sensation Novel: from The Woman in White to The Moonstone. London: Northcote House, 1994. Print. 
"queer, adj.1". OED Online. March 2013. Oxford University Press. 22 March 2013 <http://www.oed.com/view/Entry/156236? rskey=x8VjtY\&result=2>.

"queer, v.2". OED Online. March 2013. Oxford University Press. 22 March 2013 <http://www.oed.com/view/Entry/156238?rskey=TTwV1M\&result=5\&isAdv anced $=$ false $>$.

A Queer Race. Advertisement. Athenaeum 3133 (12 November 1887): 656. British Periodicals. Web. 11 Jan. 2011.

"Rachel Ray: a Novel." Rev. Athenaeum 1877 (17 October 1853): 492-4. British Periodicals. 11 Jan. 2011.

Rae, W. Fraser. "Sensation Novels: Miss Braddon." North British Review 43 (September 1865): 180-204. Print.

Reade, Charles. "Facts Must be Faced." Readiana: Comments on Current Events. By Reade. London: Chatto and Windus, 1883. 322-5. Print.

"Recent Novels: their Moral and Religious Training." London Quarterly Review 27 (October 1866): 100-24. Print.

Richards, Thomas. Commodity Culture of Victorian England: Advertising and Spectacle, 1851-1914. Stanford: Stanford UP, 1990. Print.

"The Romance of the Wreck Returns." The Pall Mall Gazette 7 November 1871: 11. $19^{\text {th }}$ Century British Library Newspapers. Web. 11 Jan. 2011.

Royle, Nicholas. Jacques Derrida. London: Routledge, 1993.

---. The Uncanny. Manchester: Manchester UP, 2003.

Shand, Alexander Innes. "Contemporary Literature. IV. Novelists." Blackwood's Edinburgh Magazine 125 (March 1879): 322-44. Print.

"The Spanish Gipsy." Rev. Saturday Review 26 (4 July 1868): 21-23. British Periodicals. Web. 11 Jan. 2011.

Stack, J. Herbert. "Some Recent English Novels.” Fortnightly Review 9 (June 1871): 731-46. Print.

Talairach-Vielmas, Laurence. Moulding the Female Body in Victorian Fairy Tales and Sensation Novels. Aldershot: Ashgate, 2007. Print.

Voskuil, Lynn M. Acting Naturally: Victorian Theatricality and Authenticity. Charlottesville and London: U of Virginia P, 2004. Print.

Wood, Ellen. East Lynne. 1861. Ed. Elizabeth Jay. Oxford: Oxford UP, 2005. Print.

---. St. Martin's Eve. 1866. London: Macmillan and Co., 1907. Print. 
Wynne, Deborah. The Sensation Novel and the Victorian Family Magazine. Basingstoke: Palgrave, 2001. Print.

Yates, Edmund. Land at Last. New York: Harper \& Brothers, Publishers, 1866. Print.

\footnotetext{
${ }^{1}$ For an obvious example, see Rae.
}

${ }^{2}$ See "For the King"; "A Queer Race"; "Loyal and Lawless" 356; "New Novels" 282; "The Romance of the Wreck Returns"; "Notices of Books" 273; and "New Books."

${ }^{3}$ Given that Collins's novel is still widely accepted as the "first" sensation novel (see Oliphant 565), my choice of exemplar is hardly arbitrary. It is, however, important to recognise that my interest lies, not in the interaction of the realistic and the sensational in this or any other single sensation novel but, rather, in how these two supposedly antithetical impulses interact to produce sensational affect more generally. As my supplemental examples suggest, this is a defining feature of the genre as a whole. ${ }^{4}$ In Acting Naturally: Victorian Theatricality and Authenticity, Lynn Voskuil argues that the somatic impact of sensation drama depends upon the interaction of the real and the spectacular. "What most astonished audiences," she claims, "was neither the sheer showiness of such stage effects nor the increasingly sophisticated technology that made them possible. Instead, playgoers were amazed because sensation scenes seemed so real" (62). "Sensation theatre, in fact, depended for its effects precisely upon this blend of seeming authenticity with an awareness of theatricality" (70). My reading of the relationship between realism and sensationalism has, inevitably, been influenced by Voskuil's work.

${ }^{5}$ As Miller argues: “The novel's 'primal scene,' which it obsessively repeats and remembers ('Anne Catherick again!') as though this were the trauma it needed to work through, rehearses the "origins" of male nervousness in female contagion—strictly, in the woman's touch" (152; emphasis added).

${ }^{6}$ See, for example, Cvetkovich 71-96 and Mangham.

${ }^{7}$ Accordingly to the Rev. Henry L. Mansel, one of the most influential of the genre's early critics, "proximity is, indeed, one great element of sensation" (488). This is confirmed by Alfred Austin, in one of the first serious attempts to define the genre: "Suffice it to say, that proximity of time is deemed indispensible to the effect they are intended to create" (412).

${ }^{8}$ In much the same way, the secret of Percival's illegitimacy is revealed neither by the original marriage register at Old Welmingham nor by its copy, but only by the difference between them. 
${ }^{9}$ For a discussion of sensation fiction's “queer continuum” (425), see Forman.

${ }^{10}$ The ontological crisis unleashed by the denaturalisation of the domestic realm and, most often, the woman at its centre, is a recurring if underexplored trope within the genre. When in East Lynne (1861), for example, Archibald Carlyle finally recognises Madame Vine for his supposedly dead wife, Isabel Vane, "the words faltered on his tongue. Did he think, as Joyce had once done, that it was a ghost he saw? Certain it is, that his face and lips turned the hue of death, and he backed a few steps from the bed.... His mind was in a whirl, his wits were scared away" (613-14). Such crises, moreover, are consistently linked to a breakdown in conceptual boundaries where the unreal becomes real. Thus, when the sensational heroine of Edmund Yates's Land at Last (1866) tells her "husband" that she is leaving him for another man, we are told that a "strange feeling, which was akin to fear of this beautiful unmasked demon, came over him, It was Margaret, his wife, who spoke thus! The knowledge and its fullest agony were in his heart; and yet a sense of utter strangeness and impossibility were there too.... Yes, this was she! It seemed impossible; but it was true" (102).

${ }^{11}$ In Chapter 17 of Adam Bede (1859), "In Which the Story Pauses a Little," Eliot promises “to give a faithful account of men and things as they have mirrored themselves in my mind" (179).

${ }^{12}$ As Eliot famously claims in Adam Bede: "I find a source of delicious sympathy in these faithful pictures of a monotonous homely existence" (179). See too: "Rachel Ray" 492; "The Cotton Lord" 464; "Atherstone Priory" 430; and "The Spanish Gipsy” 21. 